\title{
Women as Canang Sari Street Vendors in Bali
}

\author{
Ananta Wikarama Tungga Atmadja ${ }^{1 凶}$, Luh Putu Sri Ariyani ${ }^{1}$ \\ ${ }^{1}$ Faculty of Economy and Business, Ganesha University of Education
}

DOI: http://dx.doi.org/10.15294/komunitas.v8i1.5116

Received : 18 February 2016; Accepted: 29 March 2016; Published: 31 March 2016

\begin{abstract}
Every Hindu family in Bali dedicates offerings of canang sari on a daily basis. The provision of the offering is not always created by them, but they buy canang sari. This has turned canang sari into a market commodity. Therefore, women have emerged as canang sari street vendors in the several towns in Bali. This study examines the reasons why women do this job, especially in Singaraja Regency. The approach of this research was qualitative study which focused on critical social theory. The results show that the reasons women do such business activities not solely because canang sari street vendors is an informal economic sector, but also it is related to the ownership of economic, social, cultural, and symbolic capitals. This reason is strengthened by the condition of Balinese who have affected by McDonaldization society so they prefer to buy canang sari rather than making it their own.
\end{abstract}

Keywords: commodity; street vendors; women; canang sari

\section{INTRODUCTION}

The word Bali on Bali island is derived from the Sanskrit word meaning the almighty power (Wiana 2004; Davies 2007; Lesmanadan Tiliopoulos 2009). Bali is synonymous with the word Wali which means banten or offerings. This idea creates the implication that the island could be called Wali Island or Banten Island. This label is reasonable as the existence of offerings is required for all rituals that take place in the Hindu community in Bali. Banten is religiously believed to contain magical and almighty power in order to create a harmonious relationship in accordance with the ideology of Tri Hita Karana (THK) (Atmadja 2010; 2015; Picard 2011; Allen dan Palermo 2005; Gottowik 2010).

This harmonious relationship involved within the ideology of THK, among others concern with the relationship between man and God(s) with his personification. Banten which is important to realize these goals includes canang sari. Canang sari is dedicated to Hindu gods in the family temple which is done routinely in every af-

\footnotetext{
Corresponding author:
}

Address: J1. Gajah Mada VIII/12 Singaraja, Bali

Email : anantawikramatunggaatamadja@gmail.com ternoon. This condition has implications for gender roles in the family of Bali where women should be able to make canang sari. Moreover, raw materials of canang sari, like flowers, coconut leaves, betel nut, betel and other materials are relatively easy to obtain because it is available in abundance within their surrounding in Bali. Therefore, canang sari as an important element in the ritual is not only very easy to make, but also is a subsistence production which plays a central role in a family as a socio-religious unit of the people in Bali.

Because of this condition, it is not surprising if canang sari is studied by some people, such Wiana (2006, 2009), Surayin (2002, 2002a), and Adnyana (2012). The studies are mostly conducted using religion approach or sociological theory which belongs to the theory of structural functionalism and symbolic interactionism. The approach is sufficient for being able to describe the shape, function, and meaning of canang sari as well as its making procedures in the context of Hindu rituals in order to realize

(C) 2016 Semarang State University. All rights reserved p-ISSN 2086 - 5465 | e-ISSN 2460-7320 
the ideals in the ideology of Tri Hita Karana (THK).

Nevertheless, the study on Canang Sari is still needed because the previous studies have not specifically touched the procurement of Canang Sari in Balinese contemporary era where people are called as consumptive society with high level of consumerism (Atmadja 2010; Picard 2008). These conditions make Canang Sari not as subsistence production anymore, but they are put through market mechanism, resulting Canang Sari as a mere market commodity. These changes cause further implications; Canang Sari not only has using value, but also exchanging value. This idea can be proved from the emergence of many Canang Sari street vendors in Bali which is done by women. Therefore, the co-modification of Canang sari not only brings women as $\mathrm{Ca}$ nang Sari street vendors, but it also gives the chance of financial input for their household economy.

This phenomenon is interesting to be investigated not only because not many people study it, but more importantly because of the gap between expectations and reality. Hinduism ideally expects that Banten is made by people themselves as a symbol of the quality of their devotion to the Hindu gods (Wiana 2006, 2009). In addition, Canang Sari making is very easy with abundant availability of raw materials. If you cannot offer Canang sari, the Banten could be replaced with other offerings such as flowers equipped with water and incense while offering them. These conditions made people in the past not to buy Canang Sari because they could provide it independently. As a result, the dependence of Balinese people to the market for Canang Sari is not that large and their household spending would be minimized. But currently, Balinese prefer to buy Canang Sari so that the market of Canang Sari is very crowded. Hence, the co-modification of Canang sari is getting stronger which also means that there is more intense involvement of Balinese women as traders. This is reasonable because the relationship of the Balinese contemporary era and Canang Sari is inseparable.
Thus, there is an interesting question to be addressed with regard to the procurement of Canang Sari, namely: first, what causes Balinese women doing business as street vendors of Canang Sari? Second, why the Balinese as consumers prefer to buy Canang Sari instead of making it by themselves? These questions are very important because they give direction to the integrity, depth and holistic narrative constructed with regard to the involvement of women as street vendor of Canang Sari. Therefore, understanding of Canang Sari as a basic requirement for a Balinese family will be more extensive; it is no longer only about form, function and meaning as commonly done as previously, but also involves the ins and outs of procurement in accordance with the dynamics of the Balinese people who are entering the postmodern era or the era of public consumption (Atmadja 2010; McDaniel 2010; Fox 2010).

Theoretical framework used to assess the problem is not only the theory of the informal economy - considering street vendors is included in the informal sector (de Soto 1991; Damsar 2002; Telle 2013; Acri 2013), but also the theory of postmodernism concerning capital theory as put forward by Bourdieu (2011) - a variety of works examines the idea of Bourdieu (Lopez, 2014) and the theory of McDonaldization of society proposed by Ritzer (2002, 2012, 2013) and Ritzer and Goodman (2004). By adhering to these theories, a paradigm can be constructed, namely the activities of women as street vendors of Canang Sari not only because vendors is included the informal sector so that someone more freely into it, but also because they have a variety of capital. The capital that is played by Balinese women in order to increase their bargaining position in the family serves a social structure. However, what they sell through the activities of street vendors, including Canang Sari, cannot be separated from the consumers. They consume the offered goods not solely due to their need and/or desire, but it might be because they adhere to the principles in the McDonaldization of society (Weaver 2005; Ritzer and Jurgenson 2010; Franklin 2005; Denegri 
Knott and Zwick 2012).

\section{RESEARCH METHOD}

This study is a small part of a fundamental research entitled "Banten Industry Business Network and its Implications to Bali Community". The approach used was a qualitative approach based on the paradigm of postmodernism. The object of the study focused on social interaction between street vendors of Canang Sari with its customers in various cities in Bali. Considering the high number of cities in Bali, then an observation was intensively carried on to the street vendors of Canang Sari in the city of Singaraja. The informants were street vendors and consumers of Canang Sari who were appointed purposively. Data collection techniques were conducted through interview, observation and documentation study. The technique of data collection could be used separately or could also be combined in the context of triangulation data so that the validity of the data could be guaranteed. The techniques of data analysis followed the model of deconstruction as proposed by Lopez (2014). Analysis of the data led to the formation of a critical narrative which meant not only to illustrate the denotative meaning, but connotative meaning as well (Barthes 2007; Sobur, 2004; Barker, 2004, 2014).

\section{RESULTS AND DISCUSSION}

Achieving a harmonious relationship between man and gods require various efforts including the establishment of sanctuaries, namely the family temple of sanggah $\mathrm{Ke}$ mulan or a larger version which is called by daida pura (Atmadja 2010a). Kuren performs rituals at the family temple, for example $\mathrm{Ca}$ nang Sari is offered on a daily basis. These conditions result in the emergence of $\mathrm{Ca}$ nang Sari demand. The demand provides an opportunity for women to do activities as street vendors as Canang Sari.

The example can be seen in Figure 1. Figure 1 is a small example of the activities of Canang sari street vendors in some cities in Bali. Canang Sari is sold in some shape varieties: small, large round, and rectangular. Based on its name, Canang Sari consists of two important words: Canang and Sari. Canang means betel (Wiana 2006, 2009; Adnyana 2012). Betel (Piper betel) is combined with betel nut (Reca catehu) and lime to form a very famous dish. Within Balinese society, betel is called base, betel nut is called buah, and lime is called pamor. All these three materials were very famous dishes in pre-Hindu era in Southeast Asia. The dish of betel, betel nut and lime is preferred because it chemically produces alkaloid (arecadaine, areooline, and guvacine) which calms the brain and central nervous system (Reid 2014, pp.49).
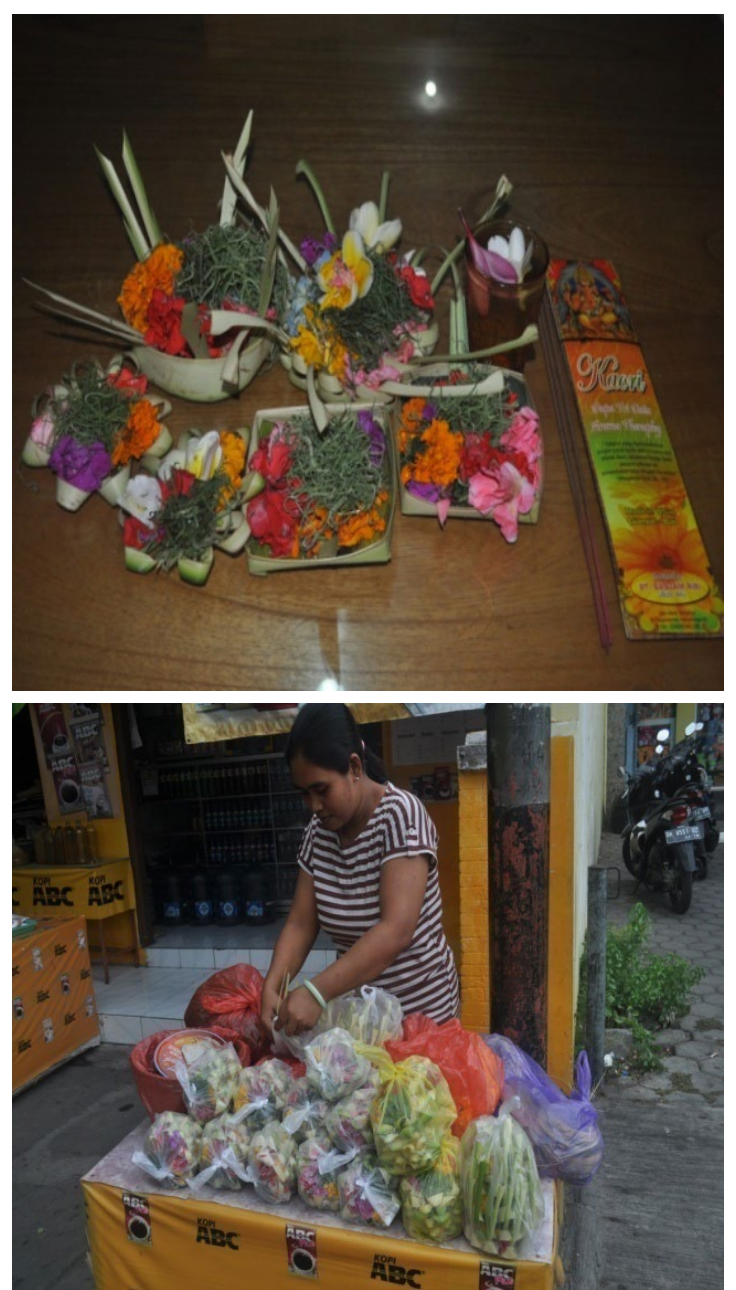

Figure 1. variations of Canang Sari commonly sold by women as street vendors of Canang Sari in several cities in Bali. In the right, a woman is arranging her Canang Sari. (Documentation Atmadja 2015).

This fact obviously shows on how 
betel, betel nut and lime are preferred by society, even they are served to guests and ancestral spirits in rituals of life cycle as a symbol of respect and / or worship (Reid 2014; Wiana 2006, 2009). Hinduization on Balinese society does not abolish the tradition of eating Canang. Galvao (in Reid 2012, pp.5o) calls it as Canang chewing, but they are persisted and incorporated into Hindu tradition in the form of Canang or renamed as Porosan. Porosan is a base that is folded to form a triangle in which there are little Buah and Pamor. Meanwhile, the word Sari means flower or flower garden. Figure 1 shows the elements of Sari plus a slice of pandan leaves, its appearance is very dominant on the Canang Sari so the porosan components become invisible.

\section{Offering Canang Sari to Pay Debt to Gods}

Hinduism outlines that the relationship between man and God (Brahman) or gods as His personification known as the god Rna is to be payable. This idea cannot be separated from the fact that life and human life depends on the gods. There are three most important deities in Hindu pantheon, Brahma the Creator, Vishnu the Preserver and Shiva the Fuser. The three gods are called Tri Murti or Tri Sakti. The universe and its contents, including humans and their culture are subject to the law of Tri Murti. Therefore, naturally, men are indebted to Tri Murti. This debt must be paid, among others, through worshiping the Tri Murti on the environment of Pakraman and Kuren Villages. It is obligatory for the people of Bali.

Canang Sari has an important function for the worship of Tri Murti on Kuren Balinese people. Canang or Porosan on $\mathrm{Ca}$ nang Sari has central position because it is not only its center of Canang Sari, but also a symbol of Tri Murti (Brahma = Buah, Vish$\mathrm{nu}=$ base , and Shiva $=$ Pamor). Flowers or Sari and pandan on Canang Sari are the symbols of purity, beauty, respect and sincerity in worship (Wiana 2006, 2009; Puja, 2007). Brahma, Vishnu and Shiva are symbolized by the three holy scripts, namely $\mathrm{A}$, $\mathrm{U}, \mathrm{M}=\mathrm{AUM}=\mathrm{OM}$. OM is a sacred script that shows the unity of Tri Murti as a determinant of life and human life, including culture that they have created. This resulted in a spell in Hindu rituals which commonly begins and ends with holy script of OM (Puja 2007; Suamba 2006).

Hence, Canang Sari is very important for Hindu rituals. Canang Sari not only serves as a symbol of respect for the Tri Murti, but also as their crown. This idea relates to Hindu theology which outlines that when people worship to the Tri Murti, then it is imagined that Canang Sari is their throne. In this way, they become immanent or transcendent, the distance becomes near. They are niskala who becomes sekala through symbolization of Canang Sari. These conditions resulted in the Balinese to feel more secure to perform the prayer of worship in accordance with its purpose at the time of prayer. Given poroson on Canang Sari is a symbol of Tri Murti $=$ OM, then the offering of Canang Sari which is done every day could be interpreted that every day Balinese spells the sacred OM in order to glorify God in his personification as Tri Murti. The spelling of sacred scripts OM is important because it has a magical power that can provide extraordinary benefit to the Hindus.

Based on such idea, it is very reasonable that the need of Canang Sari is very large and routinely conducted every day. In addition, it is also an obligation to glorify Gods name and also to pay the debt to him. Therefore, talking about the genealogy of the emergence of women as street vendors of Canang Sari is not solely due to human dreams in creating a harmonious relationship with the gods, but it also refers to the concept of God Rna. The debt to be paid among other gods must be paid through ritual by offering Canang Sari. This obligation is creatively used as a business opportunity by Balinese women in the form of street vendors of Canang Sari. This phenomenon certainly cannot be separated from various other aspects, such as increased religious awareness among the people of Bali as a result of the expansion of Hindu religious education through formal, informal and non-formal education, including the role of 
the mass media, such as TV.

\section{Reasons Women Trading Canang Sari in the Street}

The involvement of women as street vendors of Canang Sari apart as being legitimized by the Hindu religion, the god Rna and ideology THK, it is also related to other reasons which refers to the socio-cultural system. This can be observed in Chart 1 .

Referring to the notion of Bourdieu (2011), Balinese women are in the social arena, namely Kuren. Kuren is a social structure that involves power relationship between husband and wife. This relationship is based on inequality mastery of capital, i.e. economic, social, cultural and symbolic capitals. As a result, the husband (male) not only masters the woman (wife) on Kuren environment, but also they are vulnerable to violence, such violence can also be symbolic and even physical violence. Balinese women are trying to overcome this condition through activities as street vendors of Canang Sari. In this way, women hope to get financial input for her family. It is very important to remember that the lives of the
Balinese community in the era of consumption strongly held consumerism which relies heavily on money (Atmadja 2010). The financial input could also provide an opportunity for them to balance the power of their husband in the family.

Chart 1 shows that the activities of street vendors of Canang Sari also concern with equity ownership in women, namely cultural, symbolic, economic, and social capital. These four capitals form a unity that creates women who are not only able to produce Canang Sari, but also believe in their quality of women so that consumers are willing to buy it. These various capitals provide the chance for women to expand social networks in order to get good financial input as supplement for the family income in the context of fulfilling the needs and / or desires as well as to maintain the viability of the business activities as street vendors of Canang Sari.

The activities of women as Canang Sari street vendors are also concerned with the characteristics of street vendors as informal sector activity. With reference to the Damsar (2002) and based on the field observation, the informal sector characteristics

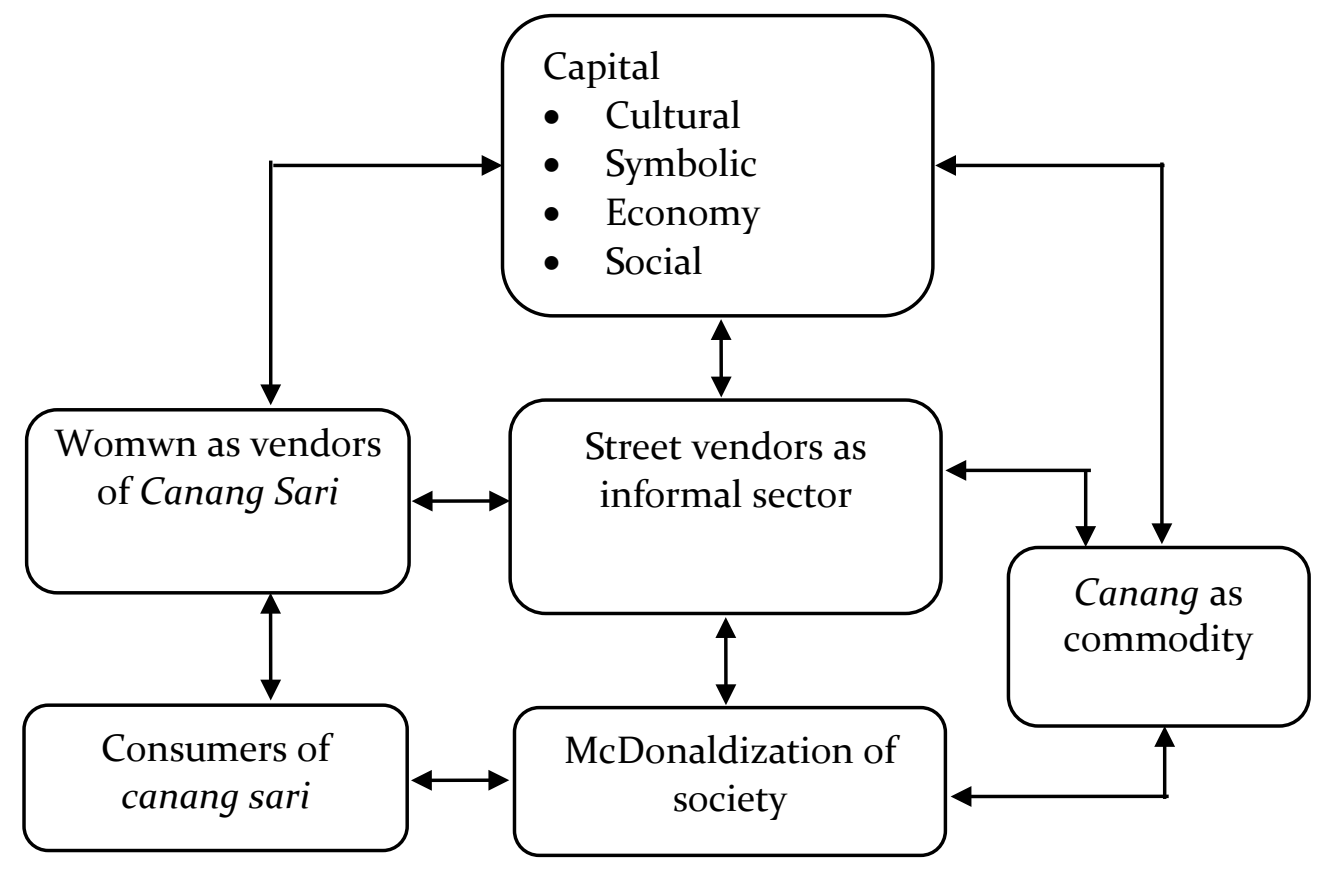

Chart 1. The Reasons of Women as Street Vendors of Canang Sari and Consumers as the buyers so the transaction of Canang Sari exists.

Source: Reconstructions based on field data (2015). 
are also applied to the Canang Sari street vendors, first, this business is easily entered. Therefore, it does not require a high level of expertise, does not require formal education, does not require a business license, does not require a lot of capital, and the organization is simple. Second, the company is family owned so the management is united with the domestic sector. Third, it is small-scale business activity so that women can control the business more easily. Fourth, it is labor intensive, and even labor can use their families including their children - husband would often help them. The transfer of the workforce could be transferred from one activity to the other because this business does not depend on any specific expertise. Fifth, the technology for making Canang Sari is very simple, namely a knife and a light socket (pin) and the raw materials which are available in the market. Sixth, Canang Sari is a basic need for all social layers at the Balinese so it has a very broad and sustainable marketing. Seventh, the business activity is flexible, such as in the time management. As a result, they can leave at any time if there is any other family and/or neighborhood business in Pakraman Village, such as village clean-up program, of ritual of death or ritual in temples. In short, the characteristics of the informal sector are very important reasons for women to pursue business activities as street vendors of Canang Sari.

\section{Consumers Experiencing McDonaldiza- tion of Society}

Women as street vendors of Canang Sari concern with consumers. If there are no consumers, vendors will not be able to sustain its operations. In connection with that, then there are important aspects that characterize consumers of Canang Sari that they embrace the principles of McDonaldization of society. This principle is global cultural elements that go to Bali along with globalization. Bali globalization has become part of the global village to global culture including the principles of McDonaldization entering Bali (Atmadja 2010). The principles of McDonaldization are the characteristics of the United States culture so that it can also be called as Americanization (Ritzer 2002, 2013).

With reference to Ritzer (2002, 2013), the applicable principles of McDonaldization are: first, the principle of efficiency. The informants said that they bought $\mathrm{Ca}$ nang Sari for reasons of efficiency in terms of time, effort, even the funds. Especially among housewives who are busy working in the office or working in the formal sector, then buying Canang Sari from female street vendors is considered more efficient than creating their own. Second is the principle of compute power. They count the consumption of Canang Sari everyday and multiply it with the money they must pay for Caang Sari. This calculation easily helps them in drawing up a household budget because they combine it with various other expenditures monthly. Thirdly, the principle of prediction, i.e. whenever and wherever they buy Canang Sari from street vendors, it can be expected the price is not much different. Similarly, Canang Sari is packaged in the plastic wrap with the shape and arrangement (tetandingan) using similar Canang Sari sockets, porosan and flower so they have standardization of products made by street vendors. Product standardization makes the consumers getting Canang Sari with such comparable quality and prices. They do not need to bargain so that the efficiency of time can be achieved.

McDonaldization principle does not just apply to the housewives who work in the formal sector, but also for those working in the informal sector, such as construction workers. They prefer being labor because when their wages are obtained, they can buy Canang Sari, and the remaining money is for the family's needs. McDonaldization principle also extends to the village reflected on the stalls and mini market in the village. Many Canang Sari street vendors pack their Canang Sari in plastic bags. Although raw material of Cacang Sari is available in fields such as leaf, base, buah, and flowers, but because of the principle of McDonaldization fad, they are reluctant to make it by themselves. The progress of infrastructure and transportation facilities has caused many 
villagers who accidentally come into town to buy Canang Sari so that the lives of street vendors in the city are getting stronger because their consumers are not only from the city, but also the village. These conditions resulted in Canang Sari street vendors, not just women of Bali, but there are also Javanese women.

Therefore, the principle of McDonaldization is widespread, even a lifestyle on the people of Bali, both in cities and villages, they rarely make Canang Sari independently. They put more emphasis on instant lifestyle in procurement of Canang Sari. In this way, the worship of Hindu gods can be channeled efficiently without causing excessive business in preparing and / or presenting Canang Sari.

\section{Patterns of Business Activity of Canang Sari Street Vendors}

Observations show that the women who work as street vendors of Canang Sari generally come from the lower classes. Their husbands work in the formal sector, such as employees or in the informal sector, a construction worker with a mediocre income. These conditions provide the impetus for women to use the capital that they have especially cultural capital in the form of skills in making Canang Sari. In this way, there is a transfer of capital into economic and cultural capitals in order to increase financial input for their families. These conditions not only give women opportunity to earn extra income for her family, but they could also indicate economic independence. Business activities as street vendors of Canang Sari, although their income is not too big, but they have an important role as a symbol of women's economic independence in order to resist the strong hegemony of patriarchal ideology on the people of Bali.

The activity of Canang Sari street vendors uses the family as a unit of production. In general, they set up the commodity at night and / or early morning. The raw materials of Canang Sari are obtained through the market, such as leaf, flower, base, buah, pamor, etc. Family members, namely mothers and children, and even her husband too, are working together to assemble (matanding) Canang Sari. They sell Canang Sari on a sidewalk in the afternoon. This relates to the habits of the Balinese in offering to Hindu gods, namely in the afternoon, at around 16:00 to 18:00

However, they can also sell Canang Sari from early morning - especially for those who sell on a road near the market. This choice relates to the fact that when people are shopping in the market to buy groceries, they also buy Canang Sari for the offering in the afternoon and / or for sudden stuffs. Similarly, people go home in the morning or during the day and happen to pass and/or, they accidentally go into the market to buy Canang Sari as offering to the gods at his family temple in the village.

The observations toward street vendors of Canang Sari in the city of Singaraja shows that the roads they use as business areas are sidewalks that are considered strategic. For example, the pavement near the Tjunction or crossroads or sidewalks that is in the densely populated area. They can even sell Canang Sari in the area near the hospital. This is reasonable because the family who care for the sick often requires Canang Sari as a means for healing from the gods toward their family members who are hospitalized. In short, women as street vendors of Canang Sari are clever in choosing the area to sell Canang Sari.

The trading patterns consist of permanent selling pattern and temporary pattern. The permanent pattern is regularly seen on their activities to continue to be there every day at the same area and time. Temporary pattern refers to selling activities on a temporary basis as they see demand increasing towards Canang Sari, for example, at the time of Purnama prayers, Tilem and Hindu holidays such as Saraswati, Galungan and Kuningan, Pagerwesi days and other days so the sidewalk in front of the Pura Jagat Natha in the city of Singaraja are filled with temporary street vendors selling Canang Sari. Similarly in Diponogoro street, the main street in the city of Singaraja is turned into a temporary Canang Sari market. The street is filled with street vendors of Canang Sari 
made by the women of the villages around the city of Singaraja. They sell Canang Sari from the afternoon until the next morning. Buleleng regency government officially grants permission for them to sell so that women can use Hindu holidays as a space to obtain additional income for their families.

The street vendors of Canang Sari not only sell ready Canang Sari, but also halfready Canang Sari - only in the form of raw material. They set it up in place to sell if their Canang Sari is sold out. They also sell other canang, for example daksina and some various equipments, such as flowers, incense, sliced Pandan, etc. Similarly, they develop good relationships with their costumers and / or provide services in the context of social capital accumulation so their market becomes steadier. In short, the street vendors of Canang Sari are very creative in diversifying their merchandise accompanied by social capital formation so that they are not only able to establish their business activities, but also benefit optimally.

\section{CONCLUSION}

THK ideology requires Balinese people to have harmonious relationship with the Hindu gods. It is not merely as a guarantee for the realization of well-being, but it is also related to the god Rna. It is equipped with the ritual which requires banten including Canang Sari. Canang Sari or nyasa is a symbol not only in the context of linggastana Tri Murti, but also a symbol of sacred script of $\mathrm{OM}$ in the context of his name to give a blessing to the welfare of mankind. Given this reality, the creation and offering of Canang Sari is not only important, but also conducted independently as a symbol of the strong devotion of the Balinese toward the Tri Murti. These conditions make Canang Sari as part of subsistence commodity.

Social changes that currently hit the Balinese people as a consequence of globalization make procurement where Canang Sari is accessed through the market as commodity. This condition cannot be separated from the ideology that comes along with globalization; Bali is stuck with consumerism so that money becomes very important.
In this context Balinese women are cleverly using a variety of its equity in order to create Canang Sari which is ready to be marketed through the activities of street vendors. The option of such activity is also related to the characteristics of street vendors as informal sector activities. Consumers also accept it because they are also stuck on the principles of McDonaldization of society.

\section{REFERENCES}

Acri, A. 2013. Modern Hindu intellectuals and ancient texts: reforming Śaiva yoga in Bali. Bijdragen tot de taal-, land-en volkenkunde/Journal of the Humanities and Social Sciences of Southeast Asia, 169(1), pp.68-103.

Adnyana, I.N.M., 2012. Arti dan Fungsi Banten sebagai Sarana Persembahyangan. Pustaka Bali Post, Denpasar.

Allen, P., dan Palermo, C. 2005. Ajeg Bali: multiple meanings, diverse agendas. Indonesia and the Malay World, 33(97),pp. 239-255.

Atmadja, N.B., 2010. Genealogi Keruntuhan Majapahit: Islamisasi, Toleransi dan Pemertahanan Agama Hindu di Bali. Pustaka Pelajar, Yogyakarta.

Atmadja, N.B., 2010a. Ajeg Bali: Gerakan, Identitas Kultural dan Globalisasi. LKIS, Yogyakarta.

Atmadja, N.B., 2014. Saraswati Dan Ganesha Sebagai Simbol Paradigma Interpretativisme Dan Positivisme: Visi Integral Mewujudkan Iptek dari Pembawa Musibah Menjadi Berkah bagi Umat Manusia. Pustaka Larasan bekerja sama dengan IBIKK BCCC Undiksha Singaraja dan Universitas Hindu Indonesia, Denpasar.

Atmadja, N.B., A. T. Atmadja, \& T. Maytai. 2015. Industri Banten Jaringan Bisnis dan Implikasinya terhadap Masyarakat Bali. Universitas Pendidikan Ganesha, Singaraja.

Barker, C., 2004. Cultural Studies Teori dan Praktik. Terjamahan Nurhadi. Kreasi Wacana, Yogyakarta.

Barker, C., 2014. Kamus Kajian Budaya. Terjemahan B. Hendar Putranto. Kanisius, Yogyakarta.

Barthes, R., 2007. Petualangan Semiologi. Terjemahan Stephanus Aswar Herwinarko. Pustaka Pelajar., Yogyakarta

Bourdieu. 2011. Choses Dites Uraian dan Pemikiran. [penerjemah. Ninik Rochani Sjams]. Kreasi Wacana, Yogyakarta.

Damsar. 2002. Sosiologi Ekonomi. PT. Rajagrafindo Persada, Jakarta.

Davies, S. 2007. Balinese aesthetics. The Journal of aesthetics and art criticism, 65(1), pp.21-29.

Denegri-Knott, J., dan Zwick, D. 2012. Tracking prosumption work on eBay: Reproduction of desire and the challenge of slow re-McDonaldization. American Behavioral Scientist, 56(4), pp.439-458.

de Soto, H., 1991. Masih Ada Jalan Lain. Yayasan Obor 
Indonesia, Jakarta.

Fox, R. 2010. Why Media Matter: Critical Reflections on Religion and the Recent History of "the Balinese". History of Religions, 49(4), pp.354-392.

Franklin, B. 2005. The local press and the McDonaldization thesis. Journalism: critical issues, pp.137.

Gottowik, V. 2010. Transnational, translocal, transcultural: Some remarks on the relations between Hindu-Balinese and Ethnic Chinese in Bali. Sojourn: Journal of Social Issues in Southeast Asia, 25(2), pp.178-212.

Lesmana, C. B., dan Tiliopoulos, N. 2009. Schizotypal personality traits and attitudes towards Hinduism among Balinese Hindus. Mental Health, Religion dan Culture, 12(8), pp.773-785.

Lubis, A.Y., 2004. Filsafat Metodologi Posmodernis. Bogor AkaDemi.

Lubis, A.Y., 2014. Potsmodernisme Teori dan Metode. PT RajaGrapindo Persada, Jakarta.

McDaniel, J. 2010. Agama Hindu dharma Indonesia as a new religious movement: Hinduism recreated in the image of Islam. Nova Religio: The Journal of Alternative and Emergent Religions, 14(1), pp.93-111.

Picard, M. 2008. Balinese identity as tourist attraction: Fromcultural tourism'(pariwisata budaya) to Bali erect'(ajeg Bali). Tourist Studies, 8(2), pp.155-173.

Picard, M. 2011. Balinese religion in search of recognition: From Agama Hindu Bali to Agama Hindu (1945-1965). Bijdragen tot de taal-, land-en volkenkunde/Journal of the Humanities and Social Sciences of Southeast Asia, 167(4), pp.482-510.

Puja, G., 2007. Wedaparikrama Himpunan Naskah Mantra dan Stotra Teks Asli Bahasa Sansekerta dan Pejelasannya. Paramita, Surabaya.

Reid, A., 2014. Asia Tenggara dalam Kurun Niaga 1450168o Jilid I: Tanah di Bawah Angin. Terjemahan Mochtar Pobotinggi. Yayasan Pustaka Obor
Indonesia, Jakarta.

Ritzer, G., 2002. Ketika Kapitalisme Berjingkrak: Telaah Kritis terhadap Gelombang Mcdonaldisasi. Pustaka Pelajar, Yogyakarta.

Ritzer, G. \& Douglas, J.G., 2004. Teori Sosiologi Modern. Kencana, Jakarta.

Ritzer, G. \& Douglas, J.G., 2012. Teori Sosiologi Dari Sosiologi Klasik Sampai Perkembangan Terakhir Posmodern. Pustaka Pelajar, Yogyakarta.

Ritzer, G. \& Douglas, J.G., 2013. Eksplorasi dalam Teori Sosial: Dari Metateori sampai Rasionalisasi. Pustaka Pelajar, Yogyakarta.

Ritzer, G., and Jurgenson, N. 2010. Production, consumption, prosumption: The nature of capitalism in the age of the digital 'prosumer'. Journal of consumer culture, 10(1), pp.13-36.

Sobur. A., 2004. Semiotika Komunikasi. PT Remaja Rosda Karya, Bandung.

Suamba, IBP., 20o6. OM Pranava Mantra. Dharmopadesa Pusat, Denpasar.

Surayin, I.A.P., 2002. Melangkah ke Arah Persiapan Upakara-Upakara Yajnya. Paramita, Surabaya.

Surayin, I.A.P., 2002a. Seri III Upakara Yajnya Dewa Yajnya. Paramita, Surabaya.

Telle, K. 2013. Vigilante citizenship: Sovereign practices and the politics of insult in Indonesia. Bijdragen tot de taal-, land-en volkenkunde/ Journal of the Humanities and Social Sciences of Southeast Asia, 169(2-3), pp.183-212.

Tim Penyusun Kamus Pusat Pembinaan dan Pengembangan Bahasa. 1995. Kamus Besar Bahasa Indonesia. PN Balai Pustaka, Jakarta.

Weaver, A. 2005. The McDonaldization thesis and cruise tourism. Annals of tourism research, 32(2), pp.346-366.

Wiana,K., 2004. Mengapa Bali Disebut Bali? Paramata, Surabaya.

Wiana,K., 2006. Sembahyang Menurut Hindu. Paramita, Surabaya.

Wiana,K., 2009. Suksmaning Banten. Paramita, Surabaya. 